\title{
GENETIC CONTROL IN METHICILLIN-RESISTANT STRAINS OF STAPHYLOCOCCUS AUREUS
}

\author{
R. W. LACEY \\ Department of Bacteriology, University of Bristol
}

Methicillin-RESISTANT strains of Staphylococcus aureus were first detected in 1960 (Jevons, 1961; Knox, 1961) and at that time comprised about 0.06 per cent. of all isolates. The frequency of methicillin resistance has gradually increased, so that by 1969 about 4 per cent. of British " hospital " strains were resistant (Parker and Hewitt, 1970). Since the use of all the penicillins and cephalosporins should favour the proliferation of these organisms, it is surprising that methicillin resistance has not become more common. Strains of Staph. aureus that are resistant to penicillin by $\beta$-lactamase production now outnumber sensitive strains both in hospital and outside (Goldie, Alder and Gillespie, 1971).

The inter-strain spread of genes may contribute to the high proportion of staphylococci resistant to other antibiotics (e.g., Novick and Morse, 1967; Richmond, 1969; Lacey, 1971 $a$ and $b$ ). Almost all methicillin-resistant strains are also resistant to streptomycin and tetracycline, and produce lactamase (Eriksen and Erichsen, 1964; Dyke, 1969; Ridley et al., 1970; Parker and Hewitt). If the gene or genes determining methicillin resistance had spread between strains, the antibiotic sensitivity of methicillin-resistant strains should be more variable than it is.

This paper attempts to account for the failure of methicillin resistance to appear in sensitive staphylococci. Although the gene or genes responsible for methicillin resistance were found to be plasmid-borne, they were transduced from lysates of the strains only at low frequency and to a narrow range of recipients. Transfer of methicillin resistance did not occur in mixed cultures. But other plasmid genes were transferred from these donors to the same recipients at medium to high frequencies.

\section{MATERIALS AND METHODS}

Staphylococci. Freeze-dried cultures of six isolates of $S$. aureus representative of methicillin-resistant types prevalent in Britain were obtained from the Cross-Infection Reference Laboratory, Colindale, in February 1969 (table I). Single colonies from each ampoule were checked for antibiotic sensitivity, bacteriophage-typed and seeded on to agar slopes (Oxoid Blood Agar Base no. 2). After overnight incubation at $37^{\circ} \mathrm{C}$, the cap of each slope was screwed down tightly and the cultures were stored at room temperature in subdued light until July 1971 (30 mth) without subculture.

Media. Nutrient broth was double-strength Bacto (Difco) with the addition of 0.5 per cent. (w/v) NaCl. Nutrient agar was prepared from Oxoid Blood Agar Base no. 2. Additional

Received 1 Mar. 1972; accepted 8 May 1972.

J. MRD. MICROBIOL. - VOL. 5 (1972) 
$\mathrm{NaCl}$ to total 5 per cent. (w/v) was added to the basic medium to detect methicillin-resistant staphylococci.

Loss of antibiotic resistance in the cultures. Preliminary subcultures indicated that substantial numbers of organisms had survived on all the slopes. Nutrient broth $(0.1 \mathrm{ml})$ was then added to each slope, and the organisms were emulsified in the broth and transferred to $9 \mathrm{ml}$ of broth and incubated for $20 \mathrm{hr}$ at $37^{\circ} \mathrm{C}$. Each culture was then diluted and spread over the surface of nutrient agar plates. After incubation overnight at $37^{\circ} \mathrm{C}$, the colonies were replicated on to nutrient agar containing $25 \mu \mathrm{g}$ per ml methicillin, or $25 \mu \mathrm{g}$ per ml streptomycin and $20 \mu \mathrm{g}$ per ml tetracycline, and in some instances containing $20 \mu \mathrm{g}$ per ml erythromycin or $3 \mu \mathrm{g}$ per ml novobiocin. The media containing methicillin were incubated for $48 \mathrm{hr}$ at $30^{\circ} \mathrm{C}$ and the others for $24 \mathrm{hr}$ at $37^{\circ} \mathrm{C}$. Selection of penicillinase-negative variants was by the method of Dyke, Jevons and Parker (1966).

TABLE I

Methicillin-resistant strains studied

\begin{tabular}{|c|c|c|c|}
\hline $\begin{array}{l}\text { Colindale } \\
\text { number }\end{array}$ & $\begin{array}{l}\text { Year of } \\
\text { initial } \\
\text { isolation }\end{array}$ & $\begin{array}{l}\text { Antibiotic } \\
\text { resistance* }\end{array}$ & Phage-typing pattern \\
\hline $\begin{array}{l}13136 \\
13137 \\
9254\end{array}$ & $\begin{array}{l}1960 \\
1960 \\
1964\end{array}$ & $\begin{array}{l}\text { MPST } \\
\text { MPST } \\
\text { MPSTE }\end{array}$ & $\begin{array}{l}\text { 7/47/53/54/75/77/84/88 (RTD) } \\
\text { 7/47/53/54/75/77/84/85/88 (RTD) } \\
\text { 29/88/ group III inhibition } \\
\text { (RTD } \times 1000)\end{array}$ \\
\hline $\begin{array}{l}2273 \\
9463\end{array}$ & $\begin{array}{l}1965 \\
1967\end{array}$ & $\begin{array}{l}\text { MPSTE } \\
\text { MPSTE }\end{array}$ & $\begin{array}{l}88 \text { (RTD) } \\
29 / 88 / \text { group III inhibition }\end{array}$ \\
\hline 11164 & 1967 & MSTENeNo & $84 / 85 / 88$ (RTD) \\
\hline
\end{tabular}

* Resistance to methicillin (M), penicillinase producer (P), resistance to streptomycin (S), tetracycline (T), erythromycin (E), neomycin (Ne), and novobiocin (No).

RTD $=$ Routine test dilution.

Antibiotic sensitivity was determined by the use of antibiotic disks (Lacey, 1971a) and also by measuring the minimum inhibitory concentration (MIC) of the antibiotic incorporated in agar in plates. Additional Mast disks used contained lincomycin $2 \mu \mathrm{g}$, oleandomycin $5 \mu \mathrm{g}$, spiramycin $5 \mu \mathrm{g}$, novobiocin $5 \mu \mathrm{g}$, or methicillin $10 \mu \mathrm{g}$. Resistance to mercury and cadmium ions was determined by the disk method of Dyke, Parker and Richmond (1970). Inocula for sensitivity tests were prepared by overnight incubation at $37^{\circ} \mathrm{C}$, after preliminary experiments at $30^{\circ}$ and $37^{\circ} \mathrm{C}$ had shown that the temperature of pre-incubation did not influence methicillin sensitivity. In tests with antibiotics other than methicillin the inoculated plates were also incubated at $37^{\circ} \mathrm{C}$. In establishing the MIC of methicillin for cultures, the methicillincontaining plates were incubated either at $30^{\circ}$ or $37^{\circ} \mathrm{C}$ and some at either temperature contained 5 per cent. $\mathrm{NaCl}$. The MIC was taken as the concentration of antibiotic that inhibited the growth of 80 per cent. or more of the inoculum (about $10^{5}$ organisms in $0.025 \mathrm{ml}$ broth) after 48 hours' incubation, unless otherwise stated. The occasional colony surviving higher levels of the drug was discounted.

Haemolysin production. Alpha- and delta-haemolysins were assayed by a semi-quantitative method. Spot inocula of the cultures were made on to agar containing 5 per cent. $(\mathrm{v} / \mathrm{v})$ rabbit or human erythrocytes and zones of haemolysis measured after 48 hours' incubation at $37^{\circ} \mathrm{C}$. Anti alpha-toxin was incorporated into control plates. Beta-lysin was detected by observing the appearance of " hot-cold " lysis.

Lipase production was detected on Tween 80 medium (Gonzalez and Sierra, 1961). Pigmentation was recorded after incubation of strains at $37^{\circ} \mathrm{C}$ for $72 \mathrm{hr}$ on 40 per cent. milk agar (Willis and Turner, 1963). 
Bacteriophage typing was done by the method of Blair and Williams (1961) with the addition of four new typing phages-no. 83A, 84 and 85 (Report, 1967) and no. 88, an experimental phage lytic for some methicillin-resistant staphylococci provided by Dr M. T. Parker, Cross-Infection Reference Laboratory, Colindale.

Mitomycin C induction was by the method of Lacey (1971b).

Propagation and harvesting of phages was by the freeze-thawing method of Williams and Rippon (1952).

Transduction of antibiotic resistance. The following procedure was generally used; variations are described where they apply. Phage preparations before each experiment were checked for sterility by plating $1 \mathrm{ml}$ on to the surface of nutrient agar in plates, which were incubated at $37^{\circ} \mathrm{C}$ for $20 \mathrm{hr}$. Volumes of the phage preparation were added, at a multiplicity of about 0.3 phage to 1 cell, to $5-\mathrm{ml}$ volumes of overnight broth cultures of the recipient in 25-ml screw-capped bottles. Calcium chloride was added to $3 \mathrm{~mm}$ and the mixtures were kept at $37^{\circ} \mathrm{C}$ for $30 \mathrm{~min}$. Sodium citrate (to $12 \mathrm{~mm}$ ) and $18 \mathrm{ml}$ of fresh pre-warmed nutrient broth were added and, after mixing, the cultures were incubated statically for a further $60 \mathrm{~min}$. at $37^{\circ} \mathrm{C}$. The cultures were then centrifuged at $3000 \mathrm{~g}$ for $10 \mathrm{~min}$. and the cells transferred to the surface of appropriate media. The recovery medium for methicillin-resistant recipients contained $12.5 \mu \mathrm{g}$ methicillin per $\mathrm{ml}$ and 5 per cent $(\mathrm{w} / \mathrm{v}) \mathrm{NaCl}$ and was incubated for 5 days at $30^{\circ} \mathrm{C}$. That for streptomycin resistance contained $50 \mu \mathrm{g}$ of the drug per $\mathrm{ml}$, for tetracycline and erythromycin resistance $20 \mu \mathrm{g}$ of each per $\mathrm{ml}$, for cadmium resistance $10^{-4} \mathrm{M}$ cadmium acetate. Apart from the transduction of methicillin resistance, all the plates were incubated at $37^{\circ} \mathrm{C}$ for $48 \mathrm{hr}$. Controls, in which no phage preparations were added, were included in each experiment.

Irradiation with ultraviolet (UV) light. Lysates of cultures, after induction with mitomycin $\mathrm{C}$, were exposed at a distance of $25 \mathrm{~cm}$ from a "Hanovia" lamp to a dose of $c .0 .28 \mathrm{ergs}$ per $\mathrm{mm}^{2}$ per s, for $15 \mathrm{~s}, 30 \mathrm{~s}, 1,2$ or $5 \mathrm{~min}$.

Transfer of antibiotic resistance between staphylococci in nutrient broth. The method used was similar to that for neomycin resistance (Lacey, 1971a); as controls the donor and recipient were incubated singly in each experiment. The recipients used were laboratory-selected mutants resistant to both novobiocin $(5 \mu \mathrm{g}$ per $\mathrm{ml})$ and rifampicin $(50 \mu \mathrm{g}$ per ml). Transfer of tetracycline, erythromycin and streptomycin resistance was detected by plating the mixed culture on media containing either $20 \mu \mathrm{g}$ per $\mathrm{ml}$ tetracycline, $20 \mu \mathrm{g}$ per ml erythromycin, or $50 \mu \mathrm{g}$ per ml streptomycin, together with $20 \mu \mathrm{g}$ per ml rifampicin. Transfer of penicillinase was detected by selecting for cadmium resistance $\left(10^{-4} \mathrm{M}\right.$ cadmium acetate) and rifampicin resistance $(20 \mu \mathrm{g}$ per $\mathrm{ml})$. Attempts to detect the transfer of methicillin resistance were made by means of recovery media containing $12.5 \mu \mathrm{g}$ methicillin per $\mathrm{ml}$ and 5 per cent. (w/v) $\mathrm{NaCl}$ with either $5 \mu \mathrm{g}$ novobiocin per $\mathrm{ml}$ or $20 \mu \mathrm{g}$ rifampicin per $\mathrm{ml}$; this medium was incubated at $30^{\circ} \mathrm{C}$ for 5 days. Other recovery media were incubated at $37^{\circ} \mathrm{C}$ for $48 \mathrm{hr}$. The frequency of transfer was expressed as the proportion of recipients, if any, that had acquired the antibiotic resistance after 18 hours' incubation with the donor.

Susceptibility to lysostaphin. Cultures were grown at $30^{\circ} \mathrm{C}$ in nutrient broth without methicillin for $48 \mathrm{hr}$, centrifuged twice at $3000 \mathrm{~g}$ for $10 \mathrm{~min}$. and resuspended in a tris buffer at $p \mathrm{H} 7.4(0.05 \mathrm{M}$ tris and $0.145 \mathrm{M} \mathrm{NaCl})$. Lysostaphin (Mead Johnson Research Laboratories, Evansville, Indiana, USA) was diluted in this buffer and added in doubling dilutions to molten nutrient agar containing 5 per cent. (w/v) $\mathrm{NaCl}$ at $45^{\circ} \mathrm{C}$. The solidified medium was inoculated with $0.025-\mathrm{ml}$ drops of the neat bacterial suspension and with cells diluted in the buffer to give about 20 colony-forming units. The inoculated plates were incubated for $48 \mathrm{hr}$ at $30^{\circ} \mathrm{C}$. The MIC was measured as the smallest amount of lysostaphin that (1) produced a greater than 50 per cent. reduction in the count from the diluted suspension and (2) that reduced confluent growth to discrete colonies from the neat inoculum.

In other experiments, $2.5 \mu \mathrm{g}$ lysostaphin per $\mathrm{ml}$ was added to the neat suspensions of cells in buffer at $30^{\circ} \mathrm{C}$ and reduction in optical density (at $620 \mathrm{~nm}$ ) on a Unicam SP600 spectrophotometer was followed for $30 \mathrm{~min}$.

Acriflavine treatment was by the method of Dornbusch, Hallander and Löfquist (1969). 


\section{RESULTS}

Loss of antibiotic resistance in six strains of Staphylococcus aureus after storage for $30 \mathrm{mth}$ at room temperature

About 5000 colonies of each strain were examined by replica plating for loss of penicillinase production (except strain no. 11164 which is not a producer), and of resistance to methicillin, streptomycin and tetracycline. Loss of erythromycin resistance was investigated in the four strains that were resistant, and loss of novobiocin resistance was investigated in strain no. 11164 . In five strains, penicillinase-negative segregants comprised from about 1 to 12 per

TABLE II

Loss of antibiotic resistance in six strains of Staphylococcus aureus stored for $30 \mathrm{mth}$ at room temperature

\begin{tabular}{|c|c|c|c|c|c|c|}
\hline \multirow{3}{*}{$\begin{array}{l}\text { Strain } \\
\text { number }\end{array}$} & \multicolumn{6}{|c|}{ Number of colonies } \\
\hline & \multirow{2}{*}{ screened } & \multicolumn{5}{|c|}{ that showed loss of resistance to } \\
\hline & & penicillin & methicillin & streptomycin & tetracycline & erythromycin \\
\hline $\begin{array}{l}9254 \\
13136 \\
13137 \\
11164 \\
2273 \\
9463\end{array}$ & $\begin{array}{l}4812 \\
5772 \\
4964 \\
5759 \\
5644 \\
4764\end{array}$ & $\begin{array}{c}607 \\
52 \\
61 \\
\dddot{247}^{*} \\
501\end{array}$ & $\begin{array}{r}0 \\
8 \\
8 \\
10 \\
3 \\
45\end{array}$ & $\begin{array}{l}0 \\
0 \\
0 \\
0 \\
0 \\
0\end{array}$ & $\begin{array}{l}0 \\
4 \\
2 \\
0 \\
7 \\
3\end{array}$ & $\begin{array}{c}0 \\
\ldots \dagger \\
\ldots \dagger \\
1 \\
21 \\
0\end{array}$ \\
\hline
\end{tabular}

* Not a penicillinase producer.

$\dagger$ Original strain sensitive to erythromycin.

cent. of the colonies (table II). No streptomycin-sensitive colonies were found, but four out of the six strains gave rise to tetracycline-sensitive derivatives. Novobiocin resistance was stable in strain no. 11164. Resistance to cadmium and mercury ions was always lost with penicillinase, and resistance to lincomycin, spiramycin and oleandomycin was lost with resistance to erythromycin in strains no. 2273 and 11164. There was no other linked loss.

\section{Properties of methicillin-sensitive segregants}

Methicillin-sensitive colonies were obtained from five of the six strains. All the sensitive colonies were tested further. The sensitive segregants (denoted $\mathrm{mtc}^{-}$) resembled the corresponding wild strains in susceptibility to other antibiotics and cadmium and mercury ions, Tween 80 reaction, haemolysin production, pigment and phage-typing pattern. All the wild strains exhibited the heterogenous type of methicillin resistance (Dyke; Parker and Hewitt) characterised by low-level resistance to methicillin of the majority of the cells when grown at $37^{\circ} \mathrm{C}$ with infrequent (about 1 in $10^{-5}$ ) resistant colonies. Reduction in temperature or the incorporation of 5 per cent. $\mathrm{NaCl}(\mathrm{w} / \mathrm{v})$ in the 
medium produced a uniformly resistant cell population. All the cocci in each of the cultures from the sensitive segregants were sensitive to methicillin under these conditions (MIC $<5 \mu \mathrm{g}$ ).

No reversions were obtained from plate cultures (about $10^{12}$ viable cocci) of one sensitive segregant of each of the five strains after plating on to nutrient agar containing $25 \mu \mathrm{g}$ methicillin per $\mathrm{ml}$ and 5 per cent. $\mathrm{NaCl}$ and incubation for 5 days at $30^{\circ} \mathrm{C}$.

\section{TABLE III}

Susceptibility to lysostaphin of methicillin-resistant strains of Staphylococcus aureus and their methicillin-sensitive derivatives

\begin{tabular}{|c|c|c|c|}
\hline \multirow{2}{*}{$\begin{array}{c}\text { Strain } \\
\text { number }\end{array}$} & \multirow{2}{*}{$\begin{array}{l}\text { Sensitivity to } \\
\text { methicillin }\end{array}$} & \multicolumn{2}{|c|}{$\begin{array}{l}\text { Minimum inhibitory concentration of } \\
\text { lysostaphin ( } \mu \mathrm{g} \text { per ml) for the } \\
\text { stated strain, in tests with }\end{array}$} \\
\hline & & $\begin{array}{c}\text { small inoculum } \\
(20 \text { organisms) }\end{array}$ & $\begin{array}{l}\text { large inoculum } \\
\text { (c. } 10^{7} \text { organisms) }\end{array}$ \\
\hline $\begin{array}{l}13136 \text { wild } \\
13136\left(\mathrm{mtc}^{-}\right)\end{array}$ & $\stackrel{\mathbf{R}}{\mathbf{S}}$ & $\begin{array}{l}0.05 \\
0.05\end{array}$ & $\begin{array}{l}1.0 \\
1.0\end{array}$ \\
\hline $\begin{array}{l}13137 \text { wild } \\
13137\left(\mathrm{mtc}^{-}\right)\end{array}$ & $\begin{array}{l}\mathrm{R} \\
\mathrm{S}\end{array}$ & $\begin{array}{l}0.025 \\
0.05\end{array}$ & $\begin{array}{l}1 \cdot 0 \\
1 \cdot 0\end{array}$ \\
\hline $\begin{array}{l}11164 \text { wild } \\
11164\left(\mathrm{mtc}^{-}\right)\end{array}$ & $\begin{array}{l}\mathrm{R} \\
\mathrm{S}\end{array}$ & $\begin{array}{l}0.05 \\
0.05\end{array}$ & $\begin{array}{l}1.0 \\
1 \cdot 0\end{array}$ \\
\hline $\begin{array}{l}2273 \text { wild } \\
2273\left(\mathrm{mtc}^{-}\right)\end{array}$ & $\begin{array}{l}\mathrm{R} \\
\mathrm{S}\end{array}$ & $\begin{array}{l}0.05 \\
0.05\end{array}$ & $\begin{array}{l}0.5 \\
1 \cdot 0\end{array}$ \\
\hline $\begin{array}{l}9463 \text { wild } \\
9463\left(\mathrm{mtc}^{-}\right)\end{array}$ & $\begin{array}{l}\mathrm{R} \\
\mathrm{S}\end{array}$ & $\begin{array}{l}0.05 \\
0.05\end{array}$ & $\begin{array}{l}1 \cdot 0 \\
1 \cdot 0\end{array}$ \\
\hline $\begin{array}{l}6936 \text { wild } \\
609 \text { wild }\end{array}$ & $\stackrel{S}{S}$ & $\begin{array}{l}0 \cdot 05 \\
0 \cdot 1\end{array}$ & $\begin{array}{l}1 \cdot 0 \\
2 \cdot 0\end{array}$ \\
\hline
\end{tabular}

$\mathbf{R}=$ Resistant $; \mathbf{S}=$ sensitive.

Five methicillin-resistant wild strains and the sensitive segregants derived from them, and two methicillin-sensitive wild strains, were tested for susceptibility to lysostaphin. The MIC of lysostaphin for all the cultures was similar both at high and low inoculum density (table III). The MIC with the higher inoculum was about 20 times that at the lower. Similarly, the rate of lysis after adding lysostaphin at $5 \mu \mathrm{g}$ per $\mathrm{ml}$ to cells suspended in tris-saline buffer was similar for all the strains whether methicillin-sensitive or resistant.

\section{Effect of acriflavine treatment on loss of methicillin resistance}

Acriflavine was added to broth cultures of strains no. $11164(5 \mu \mathrm{g}$ per ml) and no. $9463(10 \mu \mathrm{g}$ per $\mathrm{ml})$. At higher concentrations acriflavine was inhibitory. About $\mathbf{0} \cdot 2$ per cent. of the cocci of each culture had become methicillin-sensitive after acriflavine treatment but none from about 3000 cocci of control cultures grown at $37^{\circ}$ or $42^{\circ} \mathrm{C}$. These sensitive colonies resembled the wild strains in 
sensitivity to cadmium and mercury, haemolysin and penicillinase production and phage type. The sensitivity to methicillin was much more variable than that shown by the segregants occurring on storage. The MIC (at $30^{\circ} \mathrm{C}$, no added salt) for those from strain no. 11164 varied from 12.5 to $1 \cdot 5$, and those from strain no. 9463 from 25 to $3 \mu \mathrm{g}$ per ml.

\section{Transduction of methicillin resistance}

Transduction of methicillin resistance was attempted by propagating phages on the donor cultures and also by the use of lysates of them induced with mitomycin C. Typing phages no. 53 of the International Basic Set and no. 88 were propagated on strains no. 13136 and 11164 respectively. The resultant phage preparations were added to the corresponding mtc - derivatives and also to propagating strain (PS) 54 of the International Basic Set. No transductants were isolated from about $3 \times 10^{10}$ plaque-forming units (p.f.u.) of each preparation.

Lysates induced with mitomycin C were obtained from strains no. 13136, 13137, 11164 and 2273, but not from no. 9254 and 9463 . Single-colony isolates obtained from the stored cultures were generally used for induction. Transduction was attempted from each of the four lysates to each of the five $\mathrm{mtc}$ derivatives, to PS 6, 42E, 47, 53, 54, 75, 77 and 83A, and to strain no. 6936, making 56 combinations in all. From about $5 \times 10^{10}$ p.f.u. of each lysate added at a multiplicity of phage to cell of $0 \cdot 3$, transduction was achieved in three crosses only and at low frequency: from strain no. 2273 to no. $9463\left(\mathrm{mtc}^{-}\right)$, from no. 13136 to no. $11164\left(\mathrm{mtc}^{-}\right)$and from no. 11164 to no. $11164\left(\mathrm{mtc}^{-}\right)$ at frequencies of $1.3 \times 10^{-9}$ to $6 \times 10^{10}$. The failure to transduce methicillin resistance to any of the propagating strains is surprising, since tetracycline resistance was transduced to most of these from the same lysates under the same conditions. Lysates from strains no. 13136 and 13137 transduced tetracycline resistance to six of the strains at frequencies from $10^{-5}$ to $10^{-7}$, and those from no. 11164 and 2273 to all except PS 42E $\left(10^{-6}\right.$ to $\left.10^{-8}\right)$.

Transduction of methicillin resistance by means of lysates, from strain no.

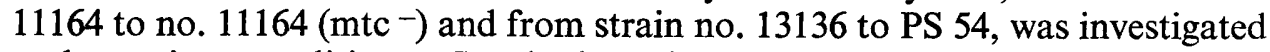
under various conditions. Incubation of the donor in sub-inhibitory concentrations of methicillin $(10 \mu \mathrm{g}$ per $\mathrm{ml})$ before induction or at $30^{\circ} \mathrm{C}$, or incubation of the recipient before and during the addition of the lysate in $0.25 \mu \mathrm{g}$ methicillin per $\mathrm{ml}$ or at $30^{\circ} \mathrm{C}$ failed to raise the transduction frequency. Also, incubation of the recipients for up to $6 \mathrm{hr}$ after adsorption of phage had an effect no more than might be accounted for by multiplication of the organisms. Increase in the phage-cell ratio from 0.3 to 3.0 and the use of the two lysates with one recipient also had little effect.

Transduction of methicillin resistance from strain no. 11164 to no. 11164 (mtc ${ }^{-}$)

The transduction of methicillin resistance from strain no. 11164 to no. 11164 $\left(\mathrm{mtc}^{-}\right)$was examined to confirm the plasmid location of the resistance and to attempt to account for the low frequencies obtained. Lysates obtained from 
three well-isolated colonies and from a subculture of the stored slope by treatment with mitomycin $\mathrm{C}$ were irradiated with UV light for varying times. With each of the lysates, an exponential decay in the transduction frequency with increasing exposure to UV light was observed. This is characteristic of most plasmid-borne genes (e.g., Arber, 1960; Asheshov, 1966, 1969). However, the initial transduction frequency from the lysate is much lower than that for most other plasmid genes (e.g., Asheshov, 1966; Dyke et al., 1970).

Six colonies of no. $11164\left(\mathrm{mtc}^{-}\right)$to which methicillin resistance had been transduced, denoted as $11164\left(\mathrm{mtc}^{-} \rightarrow \mathrm{mtc}^{+}\right)$, were investigated further. Each of the cultures of $11164\left(\mathrm{mtc}^{-} \rightarrow \mathrm{mtc}^{+}\right)$gave the same degree of heterogenous resistance to methicillin as did the wild strain no. 11164. The cultures of $11164\left(\mathrm{mtc}^{-} \rightarrow \mathrm{mtc}^{+}\right)$were induced with mitomycin $\mathrm{C}$ and transduction was attempted from the lysates to 11164 (mtc $^{-}$). From three cultures, no transductants were obtained and from the other three transduction occurred and its frequency (about $10^{-10}$ ) was stimulated more than 10 -fold in each case by small doses of UV light. This suggests a probable chromosomal location for the methicillin-resistant genes in three of the cultures of $11164\left(\mathrm{mtc}^{-} \rightarrow \mathrm{mtc}^{+}\right)$. When genetic material is transduced into a cell, it can either replicate autonomously as a plasmid, be inserted into another plasmid or else be integrated into the chromosome (Richmond and Johnson, 1969). The low frequency of transduction from strain no. 11164 (wild) may therefore possibly be due to only a fragment of the methicillin-resistant plasmid being incorporated into the phage during induction. This fragment contains the gene or genes for methicillin resistance but not areas of the plasmid genome vital for its maintenance. Thus, for phenotypic expression in the recipient, the transduced plasmid fragment becomes inserted into the chromosome.

Location of the gene or genes for penicillinase production, and for streptomycin, tetracycline and erythromycin resistance in strains no. 13136, 13137, 11164 and 2273

Mitomycin C-induced lysates prepared from single-colony isolates of each of these strains after storage were exposed to UV light for various times and then transduced to a penicillinase-negative variant of PS 54. In each case the effect of UV light on the transduction frequency was typical for either a plasmid or a chromosomal marker (table IV). These results taken in conjunction with the stability of the wild strains on storage enable the cellular location of most of the genes of these strains to be made (table V).

Transfer of resistance genes from strains no. 13136, 2273 and 11164 to four recipients in mixed culture

Cadmium resistance and penicillinase production were co-transferred at a frequency of $1 \cdot 1 \times 10^{-8}$ to $2 \cdot 2 \times 10^{-6}$ from strains no. 13136 and 2273 (table VI). Resistance to tetracycline was transferred at a frequency from $4.3 \times 10^{-5}$ to $1.2 \times 10^{-8}$ from all three strains, and erythromycin resistance, together with 
cross-resistance to lincomycin, spiramycin and oleandomycin, at from $5 \cdot 6 \times 10^{-6}$ to $6 \cdot 2 \times 10^{-8}$ from strains no. 2273 and 11164 . Resistance to streptomycin

\section{TABLE IV}

Transduction of penicillinase, and of resistance to streptomycin, tetracycline and erythromycin from mitomycin C-induced lysates of strains no. 13136, 13137, 2273 and 11164 to strain no. PS 54

\begin{tabular}{|c|c|c|c|c|c|c|c|c|}
\hline \multirow{3}{*}{$\begin{array}{c}\text { Strain } \\
\text { number }\end{array}$} & \multicolumn{8}{|c|}{ Transduction of } \\
\hline & \multicolumn{2}{|c|}{ penicillinase } & \multicolumn{2}{|c|}{$\begin{array}{l}\text { streptomycin } \\
\text { resistance }\end{array}$} & \multicolumn{2}{|c|}{$\begin{array}{l}\text { tetracycline } \\
\text { resistance }\end{array}$} & \multicolumn{2}{|c|}{$\begin{array}{l}\text { erythromycin } \\
\text { resistance }\end{array}$} \\
\hline & $\begin{array}{c}\text { Frequency* } \\
\text { with } \\
\begin{array}{c}\text { unirradiated } \\
\text { lysate }\end{array}\end{array}$ & $\begin{array}{c}\text { MVimum } \\
\text { stimulation } †\end{array}$ & $\begin{array}{c}\text { Frequency } \\
\text { with } \\
\text { unirradiated } \\
\text { lysate }\end{array}$ & $\begin{array}{c}\text { MV } \\
\text { stimulation } \dagger\end{array}$ & $\begin{array}{c}\text { Frequency } \\
\text { with } \\
\text { unirradiated } \\
\text { lysate }\end{array}$ & $\begin{array}{c}\text { MV } \\
\text { stimulation } \dagger\end{array}$ & $\begin{array}{c}\text { Frequency } \\
\text { with } \\
\text { unirradiated } \\
\text { lysate }\end{array}$ & $\underset{\text { UV }}{\text { Maximum }}$ \\
\hline 13136 & $3 \cdot 3 \times 10^{-6}$ & $x<1.0$ & $4 \cdot 1 \times 10^{-7}$ & $\times 26$ & $1 \cdot 1 \times 10^{-5}$ & $x<1.0$ & $\cdots$ & $\cdots$ \\
\hline 13137 & $4.5 \times 10^{-6}$ & $x<1 \cdot 0$ & $7 \cdot 2 \times 10^{-7}$ & $\times 33$ & $8.7 \times 10^{-5}$ & $x<1 \cdot 0$ & $\cdots$ & $\ldots$ \\
\hline 2273 & $9.5 \times 10^{-6}$ & $x<1 \cdot 0$ & $6.2 \times 10^{-7}$ & $\times 40$ & $5.0 \times 10^{-7}$ & $x<1 \cdot 0$ & $6.6 \times 10^{-6}$ & $x<1.0$ \\
\hline 11164 & $\ldots$ & $\ldots$ & $3.8 \times 10^{-8}$ & $\times 75$ & $4.9 \times 10^{-7}$ & $\times 1.5$ & $4.1 \times 10^{-8}$ & $\times 1 \cdot 2$ \\
\hline
\end{tabular}

... Strain sensitive to this antibiotic.

* Transduction frequency expressed per phage titre in unirradiated lysate.

$\dagger$ This occurred either at 15- or 30-s exposure. The reduction of phage titre by this amount of irradiation was in the range $3 \cdot 5-$ to $14 \cdot 0$-fold.

and to methicillin was not transferable. There was no other linked transfer. Methicillin resistance was also found not to be transferable from strain no. 11164 (wild) to a rifampicin resistant mutant of no. $11164\left(\mathrm{mtc}^{-}\right)$.

TABLE V

Probable location of genes in six methicillin-resistant strains of Staphylococcus aureus

\begin{tabular}{|c|c|c|c|c|c|}
\hline $\begin{array}{c}\text { Strain } \\
\text { number }\end{array}$ & $\begin{array}{l}\text { Methicillin } \\
\text { resistance }\end{array}$ & $\begin{array}{c}\text { Penicillinase } \\
\text { production }\end{array}$ & $\begin{array}{l}\text { Streptomycin } \\
\text { resistance }\end{array}$ & $\begin{array}{c}\text { Tetracycline } \\
\text { resistance }\end{array}$ & $\begin{array}{c}\text { Erythromycin } \\
\text { resistance }\end{array}$ \\
\hline $\begin{array}{l}13136 \\
13137 \\
11164 \\
2273 \\
9463 \\
9254\end{array}$ & $\begin{array}{l}\text { Plasmid } \\
\text { Plasmid } \\
\text { Plasmid } \\
\text { Plasmid } \\
\text { Plasmid } \\
\quad ?\end{array}$ & $\begin{array}{l}\text { Plasmid } \\
\text { Plasmid } \\
\quad \dagger \\
\text { Plasmid } \\
\text { Plasmid } \\
\text { Plasmid }\end{array}$ & $\begin{array}{c}\text { Chromosomal } \\
\text { Chromosomal } \\
\text { Chromosomal } \\
\text { Chromosomal } \\
? \\
?\end{array}$ & $\begin{array}{c}\text { Plasmid } \\
\text { Plasmid } \\
\text { Plasmid } \\
\text { Plasmid } \\
\text { Plasmid } \\
\text { ? }\end{array}$ & $\begin{array}{c}* \\
* \\
\text { Plasmid } \\
\text { Plasmid } \\
? \\
?\end{array}$ \\
\hline
\end{tabular}

* Sensitive to erythromycin.

$\dagger$ Does not produce penicillinase.

The failure to demonstrate transfer of methicillin and streptomycin resistance might have been due to a synergistic effect of these drugs with rifampicin. This was excluded by showing that $(a)$ there was no transfer if selection was made with novobiocin instead of rifampicin, and $(b)$ rifampicin was not demonstrably synergistic with streptomycin or methicillin in its action on the methicillinresistant strains. Methicillin resistance was also not transferred when the 
cultures were incubated at $30^{\circ} \mathrm{C}$. Failure to demonstrate recipients resistant to methicillin or streptomycin therefore probably indicates a true lack of transfer of these genes.

\section{DISCUSSION}

The finding of sensitive segregants after storage in each of the five strains examined suggests that the gene or genes controlling methicillin resistance are

TABLE VI

Transfer of resistance from Staphylococcus aureus strains 13136, 2273 and 11164 to four recipients in mixed cultures

\begin{tabular}{|c|c|c|c|c|c|}
\hline \multirow{2}{*}{$\begin{array}{l}\text { Donor } \\
\text { strain } \\
\text { number }\end{array}$} & \multirow{2}{*}{$\begin{array}{l}\text { Resistance } \\
\text { selected for }\end{array}$} & \multicolumn{4}{|c|}{$\begin{array}{c}\text { Frequency* of transfer of the stated resistance } \\
\text { to recipient strain number }\end{array}$} \\
\hline & & 609 & 6936 & PS 54 & PS 77 \\
\hline 13136 & $\begin{array}{l}\text { Methicillin } \\
\text { Penicillinase } \\
\text { Streptomycin } \\
\text { Tetracycline }\end{array}$ & $\begin{array}{c}0 \dagger \\
\text { N.T. } \\
0 \\
2.8 \times 10^{-6}\end{array}$ & $\begin{array}{c}0 \\
1.1 \times 10^{-8} \\
0 \\
1 \cdot 5 \times 10^{-6}\end{array}$ & $\begin{array}{c}0 \\
0 \\
0 \\
1 \cdot 2 \times 10^{-5}\end{array}$ & $\begin{array}{c}0 \\
\text { N.T. } \\
0 \\
4.3 \times 10^{-5}\end{array}$ \\
\hline 2273 & $\begin{array}{l}\text { Methicillin } \\
\text { Penicillinase } \\
\text { Streptomycin } \\
\text { Tetracycline } \\
\text { Erythromycin }\end{array}$ & $\begin{array}{c}0 \\
\text { N.T. } \\
0 \\
0 \\
0\end{array}$ & $\begin{array}{c}0 \\
2.2 \times 10^{-6} \\
0 \\
8 \cdot 8 \times 10^{-7} \\
5 \cdot 6 \times 10^{-6}\end{array}$ & $\begin{array}{c}0 \\
7.5 \times 10^{-8} \\
0 \\
6.1 \times 10^{-8} \\
7.9 \times 10^{-7}\end{array}$ & $\begin{array}{c}0 \\
0 \\
0 \\
0 \\
6 \cdot 2 \times 10^{-8}\end{array}$ \\
\hline 11164 & $\begin{array}{l}\text { Methicillin } \\
\text { Streptomycin } \\
\text { Tetracycline } \\
\text { Erythromycin }\end{array}$ & $\begin{array}{l}0 \\
0 \\
0 \\
0\end{array}$ & $\begin{array}{c}0 \\
0 \\
1 \cdot 2 \times 10^{-7} \\
8 \cdot 7 \times 10^{-6}\end{array}$ & $\begin{array}{c}0 \\
0 \\
4 \cdot 4 \times 10^{-8} \\
3.2 \times 10^{-6}\end{array}$ & $\begin{array}{l}\mathbf{0} \\
\mathbf{0} \\
0 \\
0\end{array}$ \\
\hline
\end{tabular}

* Frequency $=$ number of resistant recipients/total count of recipient strain after 18 hours' incubation.

$\dagger 0=$ less than $10^{-11}$ N.T. $=$ Not tested.

located on a plasmid. However, the strains had been stored for $30 \mathrm{mth}$ before the transduction experiment was performed, and it is possible that during this time a piece of chromosome might have become extruded to form a plasmid, as has been described for the genes controlling penicillinase production (Asheshov, 1969). If this had occurred in the methicillin-resistant genes of strain no. 11164 , cocci from the 30 -mth-old slope should contain a mixture of chromosomal and plasmid-located genes. But examination of a sweep and three separate colonies of this culture all gave transduction curves typical of plasmid genes. The genes for streptomycin resistance in four strains appear to be typical chromosomal determinants. If the exclusion of areas of the staphylococcal chromosome were a frequent occurrence on storage, some evidence for a plasmid location for the streptomycin resistance might be expected. It therefore seems extremely unlikely that the genes for methicillin resistance are 
normally chromosomal and have produced a plasmid on storage in each of the five cultures.

The strains described here differ in some respects from those investigated by Dornbusch et al. (1969). None of the former showed linkage of methicillin resistance to cadmium and mercury resistance, penicillinase or haemolysin production as did the Swedish strains. It is unlikely that the latter strains had heterogenous resistance to methicillin, since transduction of methicillin resistance was achieved by incubating the recovery medium at $37^{\circ} \mathrm{C}$, at which temperature only about one cell in $10^{5}$ is resistant. But in many other respects, for example, sensitivity to other antibiotics, phage type and Tween 80 reaction, the two sets of strains are similar.

Methicillin resistance in itself does not give rise to resistance to lysostaphin. However, Sabath et al. (1970) found that highly methicillin-resistant clones from heterogenously resistant strains that were incubated at $37^{\circ} \mathrm{C}$ in the presence of methicillin were more resistant to lysostaphin than a sensitive culture grown in the absence of methicillin. But methicillin-resistant staphylococci have reduced growth rates in the presence of methicillin (Sutherland and Rolinson, 1964) and this, rather than resistance to methicillin per se, might lower susceptibility to lysostaphin.

My findings may provide an explanation for the relatively slow increase in total numbers of methicillin-resistant staphylococci. Methicillin resistance was not transferred between cells in mixed cultures, and even transduction from mitomycin $\mathrm{C}$-induced lysates occurred at low frequency and to very few of the recipients tested. Transfer to a staphylococcus of genes determining resistance probably gives it an important advantage in the hospital environment. Tetracycline and erythromycin resistance, and penicillin resistance due to penicillinase production, were transferred from the same donor cultures to recipients at medium-to-high frequencies. The proportion of naturally occurring staphylococci that are resistant to these antibiotics is much higher than the proportion resistant to methicillin (Jevons et al., 1966; Ridley et al., 1970). Yet the selection pressure exerted in some instances, e.g., by erythromycin, may well have been less than that of antibiotics believed to select for methicillin resistance.

Where the probable location of the resistance genes has been determined, the findings are constant. Resistance to streptomycin is chromosomal, but penicillinase production and resistance to cadmium and mercury ions, and resistance to tetracycline and methicillin are plasmid-borne. It seems likely that most, if not all, methicillin-resistant isolates have evolved from a single origin. Resistance to antibiotics other than methicillin, streptomycin and tetracycline, and lactamase production, may have been acquired by mutation (e.g., novobiocin resistance) or by the establishment of new plasmids (e.g., neomycin and erythromycin resistance). The variation in phage-typing patterns may result from acquisition of new prophages, as has been suggested for other group III strains (Jevons et al.). There is some evidence for this in the strains studied here. Strain no. 2273 carries a phage lytic for strains no. 13136 and 13137 and strain no. 11164 carries a phage lytic for strains no. 2273, 13136 and 13137. The real danger from methicillin-resistant strains may be that they will 
acquire new resistances rather than that they will transfer methicillin resistance to other strains.

\section{SUMMARY}

Six methicillin-resistant strains of Staphylococcus aureus isolated in Britain were examined for loss of resistance after storage for $30 \mathrm{mth}$ at room temperature. Resistance to methicillin was lost from five out of six, to tetracycline from four out of six, to erythromycin from two out of four, and penicillinase from all five that were producers of it. The methicillin-sensitive segregants resembled the wild strains in bacteriophage-typing pattern, haemolysin production, Tween 80 reaction, pigmentation, and resistance to lysostaphin and to other antibiotics.

Methicillin resistance was transduced from lysates of three of the strains. Although the effect of ultraviolet light was characteristic for a plasmid gene in strain no. 11164 , transduction occurred at low frequency $\left(10^{-9-10^{-10}}\right)$ from this and from the other strains, and to a narrow range of recipients. Methicillin resistance was not transferred to recipients in mixed culture.

In contrast, plasmid genes determining lactamase production, or resistance to tetracycline or erythromycin, were transduced from lysates and transferred in mixed cultures from these strains at frequencies from $10^{-5-10^{-8}}$. These results may account for the confinement of methicillin resistance to few types of staphylococci whilst other resistance genes have become much more widespread.

I thank Professor M. H. Richmond for helpful criticism and Dr M. T. Parker for providing the strains.

\section{REFERENCES}

ARBER, W. 1960. Transduction of chromosomal genes and episomes in Escherichia coli. Virology, 11, 273.

Asheshov, ElizABETH H. 1966. Chromosomal location of the genetic elements controlling penicillinase production in a strain of Staphylococcus aureus. Nature, Lond., 210, 804.

Asheshov, ElizABETH H. 1969. The genetics of penicillinase production in Staphylococcus aureus strain PS80. J. Gen. Microbiol., 59, 289.

Blair, J. E., AND Williams, R. E. O. 1961. Phage typing of staphylococci. Bull. Wld Hlth Org., 24, 771.

Dornbusch, KaTHerine, Hallander, H. O., AND LöFQuist, F. 1969. Extrachromosomal control of methicillin resistance and toxin production in Staphylococcus aureus. J. Bact., 98, 351.

Dyke, K. G. H. 1969. Penicillinase production and intrinsic resistance to penicillins in methicillin-resistant cultures of Staphylococcus aureus. J. Med. Microbiol., 2, 261.

Dyke, K. G. H., Jevons, M. Patricia, and Parker, M. T. 1966. Penicillinase production and intrinsic resistance to penicillins in Staphylococcus aureus. Lancet, 1, 835.

Dyke, K. G. H., Parker, M. T., ANd Richmond, M. H. 1970. Penicillinase production and metal-ion resistance in Staphylococcus aureus cultures isolated from hospital patients. J. Med. Microbiol., 3, 125.

ERIKSEN, K. R., AND ERICHSEN, INGRID 1964. Resistance to methicillin, isoxazolyl penicillins, and cephalothin in Staphylococcus aureus. Acta path. microbiol. scand., 62, 255.

GoldIE, D. J., ALDER, V. G., AND GILlesPIE, W. A. 1971. Changes in the drug resistance of Staphylococcus aureus in a non-hospital population during a 20-year period. J. Clin. Path, 24, 44.

J. MED. MICROBIOL.- - VOL. 5 (1972) 
Gonzalez, C., AND Sierra, G. 1961. Lipolytic activity of some anaerobic bacteria. Nature, Lond., 189, 601.

Jevons, M. Patricia 1961. "Celbenin"-resistant staphylococci. Brit. med. J., 1, 124.

Jevons, M. Patricia, John, Madeleine, ANd Parker, M. T. 1966. Cultural characters of a newly recognized group of hospital staphylococci. J. Clin. Path., 19, 305.

Knox, R. 1961. " Celbenin "-resistant staphylococci. Brit. med. J., 1, 126.

LACEY, R. W. 1971a. High-frequency transfer of neomycin resistance between naturally occurring strains of Staphylococcus aureus. J. Med. Microbiol., 4, 73.

LACEY, R. W. 1971b. Transfer of tetracycline-resistance between strains of Staphylococcus aureus in mixed cultures. J. Gen. Microbiol., 69, 229.

Novick, R. P., AND MORSE, S. I. 1967. In vivo transmission of drug resistance factors between strains of Staphylococcus aureus. J. Exp. Med., 125, 45.

PARKer, M. T., AND HewITT, J. H. 1970. Methicillin resistance in Staphylococcus aureus. Lancet, 1, 800.

REPORT, 1967. Report of the Subcommittee on phage-typing of staphylococci of the International Committee on Nomenclature of Bacteria, Moscow, July 1966. Int. J. Syst. Bact., 17, 113.

RICHMOND, M. H. 1969. Extrachromosomal elements and the spread of antibiotic resistance in bacteria. The Fourth Colworth Medal Lecture. Biochem. J., 113, 225.

RichMOND, M. H., AND JOHNSTON, JoAN 1969. Genetic interactions of penicillinase plasmids in Staphylococcus aureus. In Bacterial episomes and plasmids, Ciba Foundation Symposium, edited by G. E. W. Wolstenholme and Maeve O'Connor, London, p. 179.

Ridley, M., Barrie, Dinah, LynN, R., and Stead, K. C. 1970. Antibiotic-resistant Staphylococcus aureus and hospital antibiotic policies. Lancet, 1, 230.

Sabath, L. D., Leaf, C. D., Gerstein, D. A., and Finland, M. 1970. Cell walls of methicillin-resistant Staphylococcus aureus. Antimicrobial agents and chemotherapy, 1969 , p. 73.

Sutherland, R., AND Rolinson, G. N. 1964. Characteristics of methicillin-resistant staphylococci. J. Bact., 87, 887.

Williams, R. E. O., AND RIPPON, JoAN E. 1952. Bacteriophage typing of Staphylococcus aureus. J. Hyg., Camb., 50, 320.

WiLlis, A. T., AND TURNER, G. C. 1963. Staphylococci in the hospital environment. J. Path. Bact.. 85, 395. 